\title{
A Pre-service English Teacher's Emotional Experiences within Teaching Practicum during COVID-19 Pandemic
}

\author{
Egi Rahmawati \\ egirw@outlook.com \\ Fauzi Miftakh \\ fauzi.miftakh@unsika.ac.id
}

Abdul Kodir Al-Baekani

abdul.kodir@fkip.unsika.ac.id

\section{Universitas Singaperbangsa Karawang}

\begin{abstract}
Research has revealed that pre-service teachers at the start of the practicum frequently experience excitement and nervousness, shock and embarrassment once they begin teaching, and guilt and regret somewhere at completion of the practicum (Zhu, 2017). Based on this problem, the study aims to explore the emotions of a male EFL pre-service teacher when undergoing English teaching practicum during COVID-19 outbreak in Indonesian academic settings and the strategies used to cope with such emotional challenges. The data were derived from interviews and diary entries and were then transcribed, arranged based on needs, and analyzed thematically using the "Emotional Geography" framework (Hargreaves, 2001a) which focusing on five emotional dimensions: physical, moral, socio-cultural, professional and political. Research findings indicate that during teaching practicum activities affected by COVID-19, the participant experienced such negative feelings such as nervousness, fear, anxiety, shock, confusion, clueless, stress, overwhelmed Ness, and powerless. However, the pre-service teacher also felt positive feelings such as compassion, happiness, relaxedness, calmness, gratitude and enjoyment after building close bonds with the community members. By this study, the researchers hope to provide broader insights and practical benefits for teachers and pre-service English teachers' development in which they can take advantage of current research results to find out what feelings might be faced in implementing English teaching practicum and what strategies can be developed and implemented to overcome these emotional problems.
\end{abstract}

Keywords: Emotional Geography; EFL Pre-service Teacher; Teaching Practicum 


\section{INTRODUCTION}

In teacher education, teaching practicum is considered as one of the most significant part (Trent, 2013) which enable pre-service teachers (PTs) to have exposures to the real situation of teaching environment. The main goal of conducting the practicum is to provide hands-on teaching experiences and activities for PTs (Ersin et al., 2020) so that they can grow any skills required to become professional teachers. However, in fact, throughout this program PTs may face a variety of problems, including a struggle to apply their cognition, personal, social, and professional values, as well as their own feelings. They are more prone to have emotional ups and downs, which could affect their professional identity (Timoštšuk \& Ugaste, 2010).

Different studies have reported that the majority of pre-service teachers are vulnerable to experiencing intense emotions, both positive and negative, during their learning-to-teach process (Bloomfield, 2010; Timoštšuk \& Ugaste, 2010). For some PTs, the teaching practicum may have been the most challenging, perplexing, difficult, and unpleasant experiences of the Bachelor degree (Farrell, 2001; FerrierKerr, 2009; Trent, 2013). Many lack of confidence in addressing severe problems in the classroom and struggle to acclimatize to school life, build connections with students and cooperate with school instructors, particularly at the beginning of the practicum (Broadbent, 1998; Fives, Hamman, \& Olivarez, 2007; GroundwaterSmith, Ewing, \& Le Cornu, 2006; Hsu, 2005; Moore, 2003). Alongside this, anxiety and frustration were also existed caused by inadequate trust and support from school mentors, particularly when they were required to control their emotions and follow the mentors' instructions (Yuan \& Lee, 2016).

Fundamentally, the experiences pre-service teachers have during the practicum can directly make a significant contribution to pre-service teachers' motivations, attitudes, identity, professional learning and engagement in the teaching profession (Day \& Leitch, 2014; Fajardo \& Miranda, 2015; Karlsson, 2013; Yuan \& Lee, 2016). Their teaching and learning, classroom management, and interactions with students, school mentors, and students' parents are all also affected by the emotional constraints they possess (Grudnoff, 2011). In other words, teaching practicum can be seen of as an emotional exercise involving the presentation of emotions in interpersonal relationships. It signifies that during their teaching practicum, preservice teachers will have emotional experiences, both positive and negative, as a series of contact with mentor teachers, students, and even their own friends. Therefore, examining the emotional dimension of pre-service teachers during practicum is critical as learning to teach is not only about applying certain technical skills, but it also includes social and emotional processes (Hargreaves, 2001b; Zembylas, 2005).

During the past decades, prior studies have brought our deep understanding on the pre-service teachers' emotional experience and identity formation. These research were conducted particularly in the context of teaching practicum in various 
academic settings, such as in Sweden (Karlsson, 2013), China (Yuan \& Lee, 2015, 2016; Zhu, 2017), and Australia (Bloomfield, 2010, O'Connor, 2008). The subject of these studies is mostly about teachers' negative and positive emotions as well as their significance in teacher identity and professional development. Whatever the emotion, there is one remarked finding concerning about teacher identity which is formed from social interactions in a specific socio-cultural and institutional setting. Nevertheless, among previous studies mentioned, study on pre-service teachers' emotion when conducting teaching practicum in Indonesian academic setting during the COVID-19 pandemic still neglected among Indonesian scholars. These issues are quite underexplored and little attention is given to how pre-service teachers derive their emotions during teaching practicum, especially amid the pandemic where the actual teaching practicum experiences in the authentic school settings have to be switched to online platforms. Hence, to fill this gap, this study presents the use of narrative study and the Emotional Geography framework (Hargreaves, 2001a) to investigate how a male EFL pre-service teacher engage his emotions during teaching practicum in the COVID-19 era as well as the strategy he used to cope with the emotional obstacles.

\section{LITERATURE REVIEW}

\section{Previous Related Study}

A number of research has been carried out by many previous researchers which focused on pre-service teachers' emotional experience, dealing with various educational contexts amid the teacher preparation (Deng et al., 2018; Timoštšuk et al., 2016; Yuan \& Lee, 2015, 2016). Deng et al. (2018) revealed that the six Chinese student-teachers during the teaching practicum experienced various emotions and dilemmas which consequence their identity formation. This study has found a pattern of the emotional experience the six student teachers have from the beginning to the end of the practicums: feeling eager and anxious at the beginning of the teaching practicums, shocked and embarrassed after the student teaching, angry and puzzled during the internship, helpless and lonely at the end of the practicums, as well as guilty and regret after the teaching practice.

Similarly, Yuan and Lee (2016)'s study also reported a narrative study investigating a pre-service language teacher from China experiencing some positive and negative feelings derived from various situations in the fieldwork. The findings showed how the participant could form teacher identity and develop their professional learning by negotiating and navigating different emotions in the process of becoming a teacher. Another research by Yuan and Lee (2015) also provides identic empirical evidence. This study investigated how three pre-service language teachers encountered various emotions arose within university coursework and teaching practicum. This study implied that pre-service language teachers are suggested to develop their identities by engaging in cognitive learning, interacting with different socializing factors and experiencing various emotions during the coursework and practicum. 


\section{Teaching Practicum}

Teaching practicum is considered as a compulsory activity within teacher education programs (Trent, 2013). This program is counted as a key stage for pre-service teachers which allows them to develop teaching skills and competencies and apply the pedagogical knowledge that they have learned in campus into practical teaching in school (Ersin et al., 2020). Not only can they learn how it is to be a teacher in a real practice (Meyer, 2009), the practicum is also done to introduce the pre-service teachers into the teaching community. This means, while completing their learningto-teach, pre-service teachers are also offered the opportunity to interact with teacher educators, school mentors, students, school administrators, as well as learn to adapt with new educational, moral, political and sociocultural contexts existed. As a result of their interactions with the aspects of schooling, pre-service teacher identity and professionalism therefore can be constructed and modified during this period (Yuan \& Lee, 2016).

\section{Emotion in Teacher Identity and Professional Learning}

Teachers may meet a wide range of emotional states as a result of situational change in their work environment as well as their social relationships with the surroundings. These emotions are constructed and reconstructed due to different social, cultural and political influences (Turner et al. 2011; Zembylas, 2010) through different areas of teachers' professional lives, such as classroom teaching, collegial relationships, and interactions with parents, which form and shape who they are as teachers (Hargreaves, 1998, 2000; Cowie, 2011). As for pre-service teachers, emotion is acknowledged as an integral element that plays a big role in teacher learning (Day \& Leitch, 2001). According to Yuan \& Lee (2015), paying attention to pre-service teachers' emotions is important since it will directly affect their professional identity and their future career. Apart from this, one potential platform where pre-service teachers can train forming their professional identities is in the pre-service teacher education program (Izadinia, 2013). Both university coursework and teaching practicum, not only allow them to learn what it is like to be a teacher through practical teaching, but they are also likely to experience a wide range of emotions as a result of their learning and relations with the community members.

However, a lack of appropriate professional training, a hierarchical relationship between pre-service teachers and teacher educators, and issues of school culture can all have a significant impact on pre-service teachers' empowerment and intelligence service (Flores \& Day, 2006). This emotional conflict and instability exposing student-teachers to feelings of vulnerability and powerlessness (El Kadri \& Roth, 2015; Kelchtermans, 1996). However, as shown in Roberts and Graham (2008)'s study, there is one strategy known as 'tactical compliance', which describes how pre-service teachers attempted to adapt in the school environment in order to acquire acceptance and approval so that they could achieve independence afterward 
the practicum (Yuan \& Lee, 2016). To this extent, examining the emotional aspects of learning-to-teach is essential to identifying how student teachers build their professional identities, which is deeply connected to professional decision and practice they will perform.

\section{Emotional Geography}

The closeness of social relationships between teachers and members of the community can bring 'understandings and misunderstandings' of different aspects of schooling (Hargreaves, 2005). These understandings and misunderstandings can create different emotions, both positive and negative, and constitute what Hargreaves calls the 'emotional geographies' of teaching (Hargreaves 2000, 2001a, 2001b, 2005). Emotional geography can be observed from experiential patterns of closeness and distance in universal human interactions with other humans (Hargreaves, 2001a, 2001b). Such patterns appear as a product or emotional construction from the existence of universal human interactions that involve physical, social, cultural, psychological, and environmental situations in which humans are present. In detail, Hargreaves (2001a) defines emotional geography as "spatial experiential patterns of closeness and/or distance in human interaction and relationships that help create, configure, and color the feelings and emotions we experience about ourselves, our world, and each other."

In his study, Hargreaves (2001) also explains in depth that there are five important dimensions that can lead to the formation of the geography of human emotions, namely the physical/personal dimension, the sociocultural dimension, the moral dimension, the professional dimension and the political dimension. First, physical geography which refers to proximity and/or gaps that occur due to the dimensions of space and time. Moral geography refers to the closeness and/or disparity caused by differences in goals and the desire to attain achievement in professional practice. Sociocultural geography is related to closeness and/or inequality that arises because of differences in gender, race, ethnicity, language and culture. Professional geography refers to the proximity and/or gaps in the existence of different understandings of professional norms and professional practices. Finally, political geography is the closeness and/or gap that is formed because of differences in understanding or perspective on power or other people who have certain positions.

\section{METHOD}

\section{Design and Sample}

The project of this research is to investigate and understand comprehensively how pre-service English language teacher's emotions are experienced in the context of online teaching practicum during COVID-19 pandemic. For that purpose, this study therefore uses narrative inquiry study to understand meanings and experience revealed in the participant's storytelling. Moreover, the study took place in a preservice English language teacher education program at one state university in 
Karawang, West Java, Indonesia. Reasons of assigning this site refer to have easiness access and meet requirements in this research. Karawang was chosen as the background in this study because the participant in this study are friends with the first author, who is currently a student at the teaching faculty mentioned. The participant of this study belongs to a male EFL pre-service teacher named David (pseudonym) who is born and raised in Bekasi and migrated to Karawang to pursue a bachelor's degree in English Education. David is a fourth-year student-teacher who was assigned to have language teaching practice at the field school as a degree requirement before receiving a teaching license.

\section{Instrument and Procedure}

Before the research began, the authors invited several student-teachers to participate voluntarily in this research. One participant, David (21), agreed to be recruited as interviewee. To collect the data, two research methods were applied. The first core set of data were derived from the participant's 'emotion diary' (Zembylas 2007b, 359). Diary method is utilized because it is suitable for studying emotions, moods, thoughts or activities across the situations happened during the school field. During the teaching practicum, the participant was encouraged to write a weekly narrative of his experience trough diaries by paying special attention to his emotional responses toward a variety of challenges in relation to teaching, classroom management, and interaction with students, school mentors, or even students' parents.

To enrich narrative data, we held two semi-structured interviews with David during the 8-week teaching practicum. Each interview session approximately lasted for 3040 minutes through Zoom application. To facilitate communication, we conducted the interviews in relaxed and conversational ways so that the participant felt comfortable and open to express his emotional experiences. All interviews were done in Indonesian language. A voice-recorder feature from Zoom application was used to record the interviews. In the interview sessions, David was requested to recount his lived experiences of conducting teaching practicum. The focus of this interview was on his initial encounters with online teaching practicum, his experiences when delivering English materials to students during online learning, his interactions with different people in the school, a variety of thoughts and feelings that emerged out of these experiences and how he coped with these situations. Additionally, he was also encouraged to narrate and clarify stories revealed in his diaries, along with the reflection on his overall teaching and learning during the program and his perceptions on the change of the educational policies he had to face at the school field which were affected by the COVID-19 outbreak.

\section{Data Analysis}

This current study uses the theoretical framework "Emotional Geography" formulated by Andy Hargreaves (2001a) to analyze the data. Data analysis is carried out by observing patterns of familiarity and/or gaps in human interactions and 
relationships. This theory consists of five closely related emotional dimensions, namely physical/personal geography, sociocultural geography, moral geography, professional geography, and political geography. The data that has been collected from diaries and interviews were then analyzed using thematic content analysis following the six steps developed by Braun et al. (2016), namely familiarization of data, initial coding, generating themes, validity and reliability of themes, defining and naming themes, and interpretation and reporting.

Before the data was coded and analyzed further, the first step was listening and transcribing the interview data. Before the data is analyzed, the data will be presented to the participants for member checking (checking interview data) and verification in order to build trustworthiness data and maintain ethics in data reconstruction (Harvey, 2005). The text collected from the diaries and interview data that had previously been transcribed was then translated into English and read repeatedly and carefully. This aims to ensure that the data already contains indicators of emotional geography, namely physical geography, moral geography, sociocultural geography, professional geography and political geography. Repeating patterns in the data will then be coded on certain words/phrases/sentences that form certain categories or topics that refer to the geographic theory of emotions. The coding is intended to be done so that the process of identifying relevant themes according to the discussion can be easily found. After having a final list of themes, the researchers defined and named each theme to help writing up the analysis of data.

\section{RESULT AND DISUSSION}

Based on the results of the thematic analysis of diary data and interviews, in this section five themes were identified and presented along with supporting data.

\section{Physical Geography: "I was very nervous and anxious. This environment was unfamiliar to me. I didn't know anyone there."}

On the first day of the school visit, David described his feelings as "nervous and anxious". This is because the school he attended was a new and unfamiliar place. What's more, he didn't know anyone at the school. But fortunately, David's level of anxiety was then reduced because he did not come there alone, but with his three other fellow students. Moreover, when he first came and made an introduction while asking for permission to do a teaching practicum, David was greeted warmly by the school's members. He explained that the teachers and staff there created a caring, warm and harmonious atmosphere so that he did not feel awkward and afraid at all even though his role there was only as an intern.

Then we asked him about the continuation of his interaction and cooperation with the mentor teacher and he explained that he did not have a big problem during the guidance process. Instead, he was feeling grateful for having been given freedom by the mentor in terms of teaching implementation style. David also stated that his 
mentor teacher was very good, friendly and easy going. During his interaction with her, he often received input, advice and systemic support which he considered quite useful and helpful for his progress and development in teaching and learning as well as adaptation to the school environment.

\section{Physical Geography: "I was afraid to meet 90+ students from all three classes but apparently having a little chit chat with them wasn't bad afterall."}

In the interview, David claimed that he is the type of person who is hard to start a conversation with strangers and not easily adaptable to new environment. When he first started teaching, David felt scared and worried at the thought of having to deal with so many students he had never met before. Even though the learning was done online, the feeling of nervousness was still there considering that this was his first experience in teaching after his arrival at the school. He also shared that he was worried about his confidence and public speaking skills. He is afraid of being awkward and cannot express his ideas in front of students. Here are the quotes in the diary and interview with David:

“... Even though it's an online meeting, I still have to deal with someone too. I feel that I am not used to public speaking yet." (Diary week 1)

"I was really nervous at first because I was going to be teaching and it would be seen by over 30 students! Online meetings don't necessarily make me dare to appear in front of many people, apparently." (Diary week 1)

From David's statement above, it can be understood that there are feelings of anxiety, tension and lack of confidence to teach and deal with students who are new to him. In his first week of teaching practicum, he was afraid that his first teaching experience would not go well. However, these worries disappeared after he got a good response from students to his presence at the school. Moreover, when asked what strategy he used to eliminate nerves and tenseness, David shared that he could be normal again after engaging in casual and deep interactions with his students.

The first and second story which tells about David's first interaction with the teacher and students provides evidence of pre-service teacher's connection with physical geography (Hargreaves, 2001). The existence of social interactions and close bonds that are built between the pre-service teacher and students and collaborated teachers are examples of strong influences on the emotional changes of pre-service teachers during the teaching practicum which then also affects classroom management and teaching performance. David's change in attitude which became more confident and had good self-control in the classroom is evidence that during practical teaching internships, the quality of relationships with students and colleagues was critical for student teachers' work motivation (Mansfield \& Volet, 2010). Meyer (2009)'s investigation in teaching practicum context also found significant student-teachers' emotional practices with students to the development of pre-service teacher identity. 


\section{Sociocultural Geography: "I don't want to make these kids feel pressured to study at home. I know they must be dizzy too."}

The determination of new way of learning during the pandemic situation has created a lot of inconvenience, difficulties and challenges for many parties, both from the teacher's and students' side. This difficult situation finally led to empathy or emotional connections between David and the students he taught. As a prospective teacher as well as a student, he understands very well the situation and how it is like to be a student who has to do learning at home during the pandemic. In this case, David as a teacher also feels the psychological burden experienced by his students. David always remembers that not all students can get good conditional privileges and support for studying at home. Therefore, he felt pity and sorry and said that he did not want to burden students much during this online learning period. Here's what David said:

"I thought not to make these kids feel pressured to study at home. I try to lighten their load because I don't know that maybe from other subjects there are teachers who give lots of assignments. I knew they must have been dizzy and overwhelmed with other subjects too, so I just gave in to the assignment process. Hopefully they can breathe a little easier towards their respective school-life." (Interview 1)

It can be seen that David felt mixed emotions about the implementation of teaching and learning activities so that later he intended to alleviate students' burden so that they could find a little comfort in their studies. David did this as a form of empathy and consideration of students' capacity and limitations in carrying out online learning. Therefore, this story contains an attachment of emotional connection and understanding (Hargreaves, 2001) between the pre-service teacher with the students which was determined by social condition during the COVID-19 outbreak.

\section{Moral Geography: "I'm in a dilemma. I don't want these students to fail."}

While in the middle of the teaching process, David encountered a moment where he found it difficult to deal with various types of students, especially students who had passive attitudes and had less motivational interest toward English learning. This becomes increasingly challenging because the teaching practice process is carried out remotely where it causes him to be unable to reprimand or approach students who have problems in learning. David said that he found some students with low scores, below the standard, some even scored 0. David himself felt guilty seeing these issues in front of him. He as a teacher does not want any of his students to fail and get a blank score in the semester report. He feels sorry and has a strong desire to be laxer when it comes to scoring. However, it turned out that his mentor teacher at that time had a different opinion with David. The mentor suggested him to act decisively against negligent students. This different set of moral standards between pre-service teacher and in-service teacher refers to moral geography (Hargreaves, 2001). 
"... Finally, the mentor teacher advised me to stay firm with the rules that I had made at the beginning. I didn't have the heart to actually give a score of 0 , but again, the mentor's provisions are just like that. Inner war? Of course. It was a moment where I really couldn't bear it because they were already in 12th grade, they were about to pass and take their exams. I don't want them to get bad grades on the report card." (Diary week 7)

\section{Professional Geography: "I was shocked, confused, clueless and stressed. But this is a responsibility I have to complete."}

It is common for pre-service teachers to feel a 'reality shock' (Veenman, 1984, p.143) at the first time they do school-based practicum. This can happen due to the transition of the learning environment from the university to the school placement. In David's case, the shock he felt was related to the preparation of learning which includes the making of lesson plans and materials before starting to teach in class. The feeling of shock was also accompanied by feelings of confusion, clueless and stress as well, considering that he had never had teaching experience in schools other than microteaching experiences on campus.

However, despite all the difficulties that exist, David tried to survive and forced himself to be strong in facing and solving these problems. According to him, being independent, serious, accepting constant critics and advices, realizing, reflecting and correcting his mistakes, increasing motivation, and being responsible are the right actions that can build his professionalism. In addition, David also did not forget to get enough rest and maintain communication with his fellow friends to regain emotional balance within himself.

"As time goes by, I try to keep improving myself because I feel I have a responsibility to teach these students and because this is a compulsory subject on campus that must be done as a graduation requirement." (Interview 1)

\section{Professional Geography: "I have to be good at dividing my time between attending lectures and teaching practice."}

For David, the implementation of the eight-week teaching practicum was accompanied by the implementation of KKN (student study service) and several other compulsory subjects. He shared that there were times when his academic activities on campus had to collide with his teaching schedule at the school field. The complexity of the time allocation for these activities turned out to have a psychological impact on David. In addition to getting physical collapse due to lack of rest, he also has to deal with mental problems where he feels stressed and overwhelmed because his focus was often divided on many things.

"Some schedules are quite conflicting. Often my teaching time collides with class schedules in the 7th semester. Along with the teaching schedule on Monday in the morning, there is a compulsory research proposal course. Yes, there are KKN 
(students community service) and PLP (teaching practicum) programs and I also must attend some compulsory courses. To be honest, the whole thing overwhelmed me because my focus was divided." (Diary week 1)

From David's statement above, there are indications that a period of overwhelming moment that he passed at first could lead to negative emotions and affected his growing identity as a professional teacher. Under such pressure and so much busyness, he chose to deal with it wisely. He continues to try to study the situation, make a timetable schedule and obey one by one of his activities in a structured manner so that his little time can be divided properly for all his activities. In overcoming time management problems during the teaching practicum period, David made various attempts, starting from making video-based materials to shifting/substituted lecture schedules.

Instead of constantly feeling down, David chose to keep trying to live what he is facing while diverting these negative emotions into several positive activities as a form of survival strategy. This part of the story implicates the professional geography (Hargreaves, 2001) existence where David showcases his willingness to tackle difficulties and keep his professional work within teaching practice despite all of these conflicting emotions he faced. This aligns with the concept of 'emotional intelligence' (Salovey \& Mayer, 1990), which can assist teachers in dealing with the emotional complexity of teaching and developing a strong and positive professional identity. Pre-service teachers who have good emotional intelligence have proven to be able to survive in dealing with problems in the school field and can even result in identity improvements, teaching performance, and even future careers.

\section{Political Geography: "My mentor teacher suggested not to do synchronous learning too long."}

David initially intended to carry out various kinds of exploration in terms of English language teaching in the classroom so that his students could experience fun and meaningful language learning. However, the implementation of this online learning process at the school where David teaches came as a contrast with his willing. The reality of the learning situation at the school was not enough to support various types of teaching techniques and methods considering the fact that most of the students there are struggling in carrying out full online learning. There are many inconveniences and unpreparedness that students often complain about, especially the problem of internet access. In the early weeks of teaching, David's mentor teacher even had time to tell him that if synchronous learning was carried out too often at the school, it was feared that it would cause problems for students both financially and psychologically. Therefore, when David came to teach there, he was instructed by his mentor not to ask his students to do synchronous learning too often. According to his mentor, in this uncertain pandemic situation, students' wellbeing is a priority over academic activities. For this reason, David chose to 
dominate asynchronous learning by uploading video material online as a solution to this problem.

\section{"I followed the instruction from my mentor teacher in which she suggested doing Zoom meetings, but not too often for fear that the students would run out of internet data. (...) Because of that, I finally decided to make pre-recorded lessons." (Interview 1)}

David's statement above is an evidence of the pre-service teacher's struggle with political geography (Hargreaves, 2001) in which the power structure at school could impact the interaction process and student-teacher's practical learning (Liu, 2016; Yuan, 2016). His existence as a student teacher made him realize that his position at the school was only as a newcomer and an intern so that he inevitably had to adapt to the social and cultural conditions that had been built in the school. His status as a student-teacher also turned out to be a bit limiting for him to explore teaching modes through certain media according to his initial wishes. For some reason, he finally decided to follow the instructions of his mentor in the practicum.

Van Veen et al. (2005) and Zembylas (2005) explained that pre-service teachers' interactions with school systems, culture, and power structure could form and develop their emotions and identities. This can be seen in David's case where the school rules and mentor's demand have taken David's professional autonomy which created obstacle for his learning-to-teach process as a student-teacher (Timoštšuk \& Ugaste, 2010; Yuan, 2016). His chance to offer students the opportunities to experience fun and interactive language learning was also lost because he had to follow the advice of his mentor to teach using video-taped materials.

\section{CONCLUSION}

This study describes a narrative study of emotional experience from a male student majoring in English education who conducted teaching practicum during the COVID-19 pandemic. The data obtained shows that there are various kinds of emotions that arose from the pre-service teacher during the practicum. These emotions include feelings of nervousness, fear, anxiety, shock, confusion, clueless, stress, overwhelmed Ness, powerlessness, compassion, relaxedness, calmness, happiness, enjoyment, and gratitude. This collection of emotions emerged as a result of various events such as the adjustment with new environment, interactions and relationships with students, mentor teachers, and collaborated teachers, preparation before teaching practice, and time division between campus life and teaching practice. Furthermore, the study also stresses on the importance of independence, seriousness, motivation, responsibility, self-reflection, time management, and social support as a coping-strategy to help the pre-service teacher face, manage, and reduce the emotional obstacles during the practice. 


\section{REFERENCES}

Bloomfield, D. (2010). Emotions and 'getting by': A pre-service teacher navigating professional experience. Asia-Pacific Journal of Teacher Education, 38, 221234.

Braun, V., Clarke, V., \& Weate, P. (2016). Using thematic analysis in sport and exercise research. 191-205. Routledge.

Cowie, N. (2011). Emotions that experienced English as a Foreign Language (EFL) teachers feel about their students, their colleagues and their work. Teaching and Teacher Education, 27, 235-242.

El Kadri, M. S., \& Roth, W. M. (2015). The teaching practicum as a locus of multilevelled, school-based transformation. Teaching Education, 26, 17-37.

Flores, M. A., \& Day, C. (2006). Contexts which shape and reshape new teachers' identities: A multi-perspective study. Teaching and Teacher Education, 22, 219-232.

Grudnoff, L. (2011). Rethinking the practicum: Limitations and possibilities. AsiaPacific Journal of Teacher Education, 39, 223-234.

Hargreaves, A. (2000). Mixed Emotions: Teachers' Perceptions of their Interactions with Students. Teaching and Teacher Education, 16 (8): 811826.

Hargreaves, A. (2001a). The Emotional Geographies of Teachers' Relations with Colleagues. International Journal of Educational Research, 35: 503-527.

Hargreaves, A. (2001b). Emotional Geographies of Teaching. Teachers College Record, 103(6): 1056-1080.

Hargreaves, A. (2005). Educational Change Takes Ages: Life, Career and Generational Factors in Teachers' Emotional Responses to Educational Change. Teaching and Teacher Education, 21: 967-983.

Izadinia, M. (2013). A review of research on student teachers' professional identity. British Educational Research Journal, 39, 694-713.

Karlsson, M. (2013). Emotional identification with teacher identities in student teachers' narrative interaction. European Journal of Teacher Education, 36, $133-146$.

Liu, Y. (2016). The emotional geographies of language teaching. Teacher Development, 20(4), 482-497. DOI: 10.1080/13664530.2016.1161660

Meyer, D. (2009). Entering the emotional practices of teaching. In P. A. Schutz \& M. Zembylas (Eds.), Advances in teacher emotion research (pp. 73-91). Springer.

O'Connor, K. (2008). 'You choose to care': Teachers, emotions and professional identity. Teaching and Teacher Education, 24, 117-126.

Roberts, J., \& Graham, S. (2008). Agency and conformity in school-based teacher training. Teaching and Teacher Education, 24, 1401-1412.

Schutz, P., \& Zembylas, M. (2009). Introduction to advances in teacher emotion research: The impact on teachers' lives. In P. A. Schutz \& M. Zembylas (Eds.), Advances in teacher emotion research (pp. 3-11). Springer.

Timoštšuk, I., \& Ugaste, A. (2010). Student teachers' professional identity. Teaching and Teacher Education, 26, 1563-1570. 
Turner, J., R. Waugh, J. Summers, and C. Grove. (2011). Implementing Highquality Educational Reform Efforts: An Interpersonal Circumplex Model Bridging Social and Personal Aspects of Teachers' Motivation. In Advances in Teacher Emotion Research, edited by P. Schutz and M. Zembylas, 253272. Springer.

van Veen, K., P. Sleegers, and P. van de Ven. (2005). One Teacher's Identity, Emotions, and Commitment to Change: A Case Study into the Cognitiveaffective Processes of a Secondary School Teacher in the Context of Reforms. Teaching and Teacher Education, 21: 917-934.

Yuan, R., \& Lee, I. (2015). The cognitive, social and emotional processes of teacher identity construction in a pre-service teacher education programme. Research Papers in Education, 30, 469-491.

Yuan, R., Lee, I. (2016). 'I need to be strong and competent': a narrative inquiry of a student-teacher's emotions and identities in teaching practicum. Teachers and Teaching, DOI: 10.1080/13540602.2016.1185819

Zembylas, M. (2002). Constructing Genealogies of Teachers' Emotions in Science Teaching. Journal of Research in Science Teaching, 39 (1): 79-103.

Zembylas, M. (2005). Discursive Practices, Genealogies, and Emotional Rules: A Poststructuralist View on Emotion and Identity in Teaching. Teaching and Teacher Education, 21: 935-948.

Zembylas, M. (2007a). Emotional Ecology: The Intersection of Emotional Knowledge and Pedagogical Content Knowledge in Teaching. Teaching and Teacher Education, 23: 355-367.

Zembylas, M. (2010). Teachers' Emotional Experiences of Growing Diversity and Multiculturalism in Schools and the Prospects of an Ethic of Discomfort. Teachers and Teaching, 16 (6): 703-716. 